\title{
Extraction of Non-ferrous Metals as Inorganic Chlorides from Waste Lead Slags in the Presence of Chlorine-containing Components of a Distilled liquid
}

\author{
DANA TEMIRBEKOVNA PAZYLOVA*, VIKTOR MIKHAYLOVICH SHEVKO, \\ ALIBEK SPABEKOVICH TLEUOV, NURILA SAIDULLAEVNA SAIDULLAYEVA, \\ ASIYA SALIDINOVNA ABZHANOVA and NURZHAMAL MAHAMATOVNA ABLYAZIMOVA
}

\author{
South Kazakhstan State University Named after M. Auezov, 160012,Tauke Khan Avenue 5., \\ Shymkent, Kazakhstan. \\ *Corresponding author E-mail: danapazyl@mail.ru
}

http://dx.doi.org/10.13005/ojc/350152

Received: December 08, 2018; Accepted: January 26, 2019)

\begin{abstract}
The presented article contains the research results on extraction of non-ferrous metals as inorganic chlorides from waste lead slags in the presence of chlorine-containing components of a distilled liquid-calcium and sodium chlorides. The research was implemented by a thermodynamic modelling technique using a software package HSC-5.11 Chemistry, based on a Gibbs energy minimum principle, and also a rototable second-degree method of planning an experiment (Box-Hunter method). It was found, that at equilibrium conditions lead is extracted from slags by chloride sublimation the most effectively, then zinc and copper: at pressure of 1 bar and temperature of $1500^{\circ} \mathrm{C}$ the chloride sublimation degree for lead makes $98.63 \%$, for zinc $-64.45 \%$ and for copper $-21.91 \%$. To achieve the $95-100 \%$ lead chloride sublimation degree the necessary temperature is $933.7-1300^{\circ} \mathrm{C}$ and $\operatorname{lgP}$ should be from -0.48 to -1.75 (pressure of $0.33-0.0177$ bar); for achievement of the $90.0-100 \%$ chloride sublimation degree for zinc respective parameters are $T=1279.3-1500^{\circ} \mathrm{C}$ and $\operatorname{lgP}$ from -0.972 to -2 (pressure of $0.107-0,01$ bar), for copper - temperature of $1337.7-1500^{\circ} \mathrm{C}$ and IgP from -1.418 to-2 (pressure of $0.038-0.01$ bar). It was experimentally proved, that at the sinter-chlorinating roasting at temperature of $1150-1180^{\circ} \mathrm{C}$ and pressure of $0.006-0.001$ bar the chloride sublimation degree for lead makes $93-98 \%$, for zinc $-82-96 \%$, for copper $-73-88 \%$.
\end{abstract}

Keywords: Fuming slags, Distilled liquid, Sodium and Calcium chlorides, Thermodynamic
modelling, Sinter-chlorinating roasting, Chloride sublimation of lead, Zinc and copper.

\section{INTRODUCTION}

The ammoniac way prevailing in the world soda production gives a considerable quantity of a liquid waste product - distilled liquid. Its composition, $\mathrm{g} / \mathrm{m}^{3}$ : $\mathrm{CaCl}_{2}-118-125 ; \mathrm{NaCl}-58.6-$ 80; $\mathrm{CaCO}_{3}-6-15 ; \mathrm{CaSO}_{4}-2-2.7 ; \mathrm{Mg}(\mathrm{OH})_{2}-3-10$; $\mathrm{CaO}-2-4 ; \mathrm{Fe}_{2} \mathrm{O}_{3}+\mathrm{Al}_{2} \mathrm{O}_{3}-1-3 ; \mathrm{SiO}_{2}-1-41$. There are some directions of partial recycling of the distilled liquid that allows obtaining: waterless calcium

This is an Open Access article licensed under a Creative Commons license: Attribution 4.0 International (CC- BY). Published by Oriental Scientific Publishing Company @ 2018

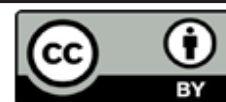


peroxide used for production of bleachers and disinfectants and for treatment of waste water and gas emissions ${ }^{2}$; phosphorus-containing fertilizers applied in agriculture ${ }^{3}$; ammonium chloride, which can be used in the textile industry, pharmaceutics, at soldering of metals, tinning, for filling of galvanic cells, as a nitric fertilizer ${ }^{4}$; high-quality chemicallyprecipitated calcium carbonate widely used in many industries for manufacturing various composite materials ${ }^{5}$. After special preparation the distilled liquid can be applied for pumping in oil wells for the purpose of maintenance of strata pressure ${ }^{6}$. But such the way of its recycling is possible only if soda ash manufacture is situated in the oil recovery area. There is a method of electrochemical processing of the distilled liquid with obtaining $\mathrm{Ca}(\mathrm{OH})_{2}, \mathrm{NaOH}$ and $\mathrm{HCl}^{7}$. Also the distilled liquid is used at soda ash manufacturing by means of processing of a salt solution for desulfation of a brine and production of gypsum ${ }^{8}$. We suggest to use the distilled liquid for extraction of nonferrous metals as inorganic chlorides fromfuming slags.

\section{EXPERIMENTAL}

\section{Materials and Methods}

At implementation of the research we applied the fuming slags of JSC «Yuzhpolimetal» containing (\%): $\mathrm{ZnSiO}_{3}-6.4 ; \mathrm{ZnS}-1.5 ; \mathrm{Cu}_{2} \mathrm{O}-1.5$; $\mathrm{PbS}-0.2 ; \mathrm{PbSO}_{4}-0.2 ; \mathrm{SiO}_{2}-22.7 ; \mathrm{Fe}_{2} \mathrm{O}_{3}-40.1$; $\mathrm{CaO}-13.9 ; \mathrm{MgO}-3.1 ; \mathrm{Al}_{2} \mathrm{O}_{3}-5.4 ; \mathrm{MnO}-0.7 ; \mathrm{Na}_{2} \mathrm{O}-$ 2.91; others -1.4. A mixture of calcium and sodium chlorides with a mass ratio of $\mathrm{CaCl}_{2} / \mathrm{NaCl}=2$ (such the chloride ratio is typical of the distilled liquid. Its composition, $\mathrm{g} / \mathrm{m}^{3}: \mathrm{CaCl}_{2}-118-125 ; \mathrm{NaCl}$ - 58.680; $\mathrm{CaCO}_{3}-6-15 ; \mathrm{CaSO}_{4}-2-2.7 ; \mathrm{Mg}(\mathrm{OH})_{2}-3-10$; $\left.\mathrm{CaO}-2-4 ; \mathrm{Fe}_{2} \mathrm{O}_{3}+\mathrm{Al}_{2} \mathrm{O}_{3}-1-3 ; \mathrm{SiO}_{2}-1-4\right)$ was used as a chlorinating agent. The chlorides content was constant and equal $6.8 \%$ of $\mathrm{CaCl}_{2}$ and $3.4 \%$ of $\mathrm{NaCl}$ of the slag weight. The oxygen mass also was constant and made $100 \%$ of the theoretically necessary weight for oxidation of lead and zinc sulphides to their oxides.

The research was implemented by a thermodynamic modelling technique using a software package HSC-5.11 Chemistry, based on a Gibbs energy minimum principle ${ }^{9}$, and also a rototable second-degree method of planning an experiment (Box-Hunter method) ${ }^{10}$. First of all, we studied the pressure and temperature effect on the quantitative distribution of substances in a system under study, and then on the basis of the obtained data
- the equilibrium chloride sublimation degree $\left(\alpha_{\mathrm{ch}}\right)$ of lead, zinc and copper. The metals' chloride sublimation degree was calculated according to the expression:

$\alpha_{c h l}(\mathrm{Me})=\left[\frac{G_{m e t}(\mathrm{chl})}{G_{\text {met (in) }}}\right] \cdot 100$

Where $G_{\text {met (chl) }}$-weight of a metal turned into chloride, $\mathrm{kg} ; \mathrm{G}_{\text {met (in) }}$ - weight of a metal in slag, $\mathrm{kg}$.

\section{RESULTS AND DISCUSSION}

Temperature and pressure effect on the quantitative distribution of the substances containing lead, zinc and copper in a system slag $-\left(\mathrm{CaCl}_{2}+\mathrm{NaCl}\right)-\mathrm{O}_{2}$

Figure 1 contains the information obtained by means of the software packageHSC-5.11 about the quantitative distribution of the substances containing lead, zinc and copper at pressure of 1 and 0,1 bar. As follows from the figure, lead in the studied system is as $\mathrm{PbCl}_{2}, \mathrm{PbCl}_{2}(\mathrm{~g}), \mathrm{PbCl}(\mathrm{g}), \mathrm{PbSO}_{4}$; zinc as $\mathrm{ZnSiO}_{3}, \mathrm{ZnCl}_{2}(\mathrm{~g}), \mathrm{ZnCl}_{2}$ and copper as $\mathrm{Cu}_{2} \mathrm{O}$, $\mathrm{CuCl}, \mathrm{CuCl}_{2}(\mathrm{~g}), \mathrm{CuCl}(\mathrm{g})$. Decrease in the pressure promotes increase in $\alpha \mathrm{chl}(\mathrm{Me})$ and reduction of the process temperature.

Temperature effect on the chloride sublimation degree of lead, zinc and copper from the slag in the presence of $\mathrm{CaCl}_{2}$ and $\mathrm{NaCl}$

Influence of temperature and pressure on $\alpha \mathrm{chl}(\mathrm{Me})$ is represented in Figure 2.

Judging from the Fig. 2 the decrease in pressure and increase in temperature leads to increase in $\alpha_{c h l}(\mathrm{Me})$. We accept $\alpha_{c h l}(\mathrm{~Pb})>\alpha_{\mathrm{chl}}(\mathrm{Zn})>\alpha_{\mathrm{chl}}(\mathrm{Cu})$.

\section{The research matrix and results}

The research matrix (according to the second-degree rototableplanning) and results are represented in Tables 1-3. On the basis of the results the regression equations of temperature $\left(T,{ }^{\circ} \mathrm{C}\right)$ and pressure (IgP, bar) influence on the chloride sublimation degree of lead $\left(\alpha_{\mathrm{chl}}(\mathrm{Pb}), \%\right)$, zinc $\left(\alpha_{\mathrm{chl}}(\mathrm{Zn})\right.$, $\%)$ and copper $\left(\alpha_{\mathrm{chl}}(\mathrm{Cu}), \%\right)$ were obtained:

$\alpha_{c h l}(P b)=-114.491-60.08 \cdot \lg P+0.2772 \cdot-5 \cdot(\lg P)^{2}-$ $9.08 \cdot 10^{-5} \cdot \mathrm{T}^{2}+0.0367 \cdot \lg P \cdot \mathrm{T}$;

$\alpha_{c h l}(Z n)=-622.1-101.8 \cdot \lg P+0.823 \cdot T-7.7^{2} \cdot(\operatorname{lgP})^{2}-$ $2.44 \cdot 10^{-4} \cdot \mathrm{T}^{2}+0.045 \cdot \lg \mathrm{P} \cdot \mathrm{T}$;

$\alpha_{c h l}(\mathrm{Cu})=-1635.89-164.44 \cdot \operatorname{lgP}+2.103 \cdot \mathrm{T}-7.76 \cdot(\mathrm{lgP})^{2}-$ $6.62 \cdot 10^{-4} \cdot \alpha \mathrm{T}^{2}+0.0735 \cdot \lg \mathrm{P} \cdot \mathrm{T}$. 

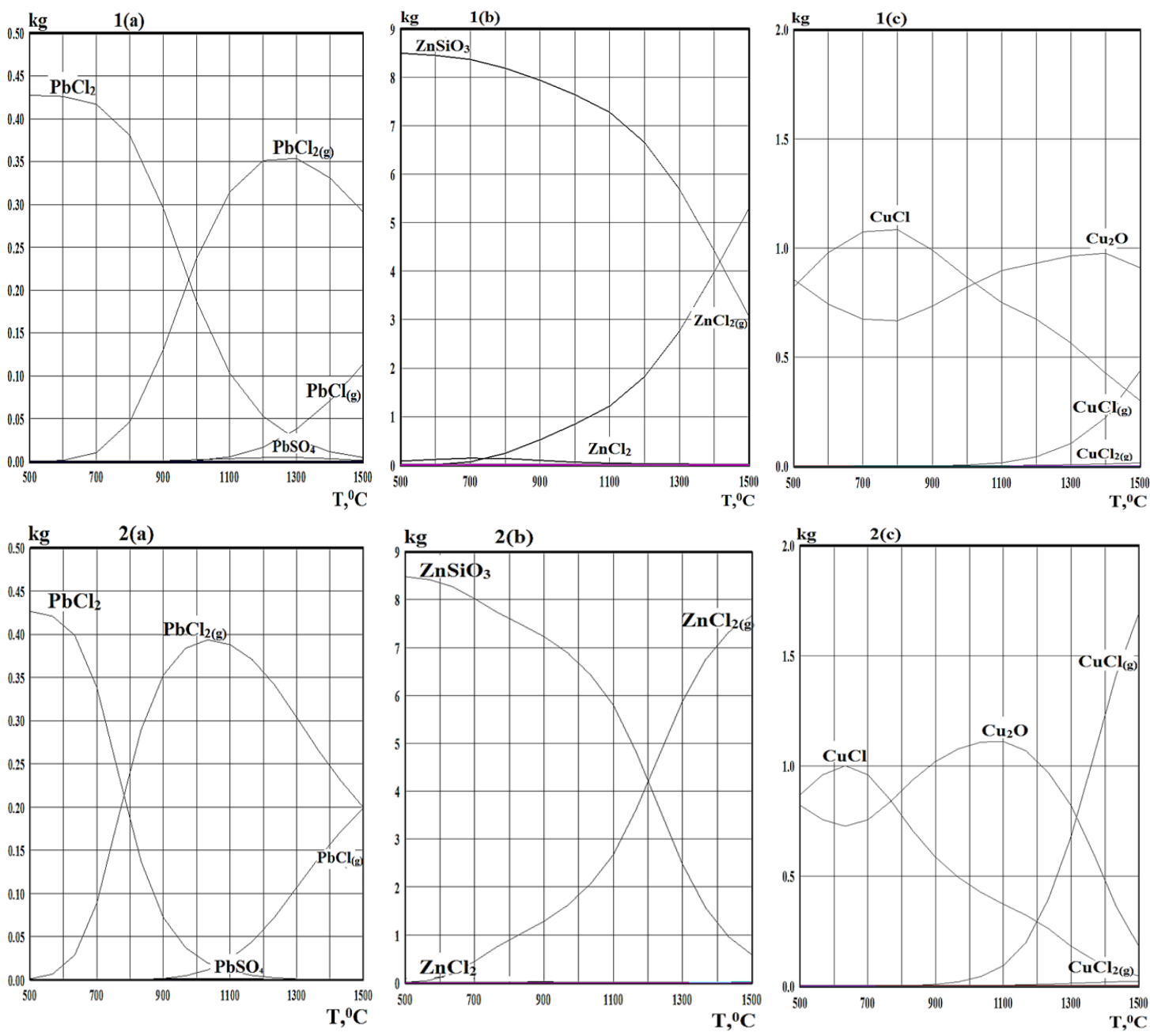

1- pressure of 1 bar; 2 - pressure of 0,1 bar

The quantitative distribution of the substances containing: a) lead; b) zinc; c) copper

Fig. 1. Temperature and pressure effect on the quantitative distribution of the substances containing lead, zinc and copper in a system slag $-\left(\mathrm{CaCl}_{2}+\mathrm{NaCl}\right)-\mathrm{O}_{2}$
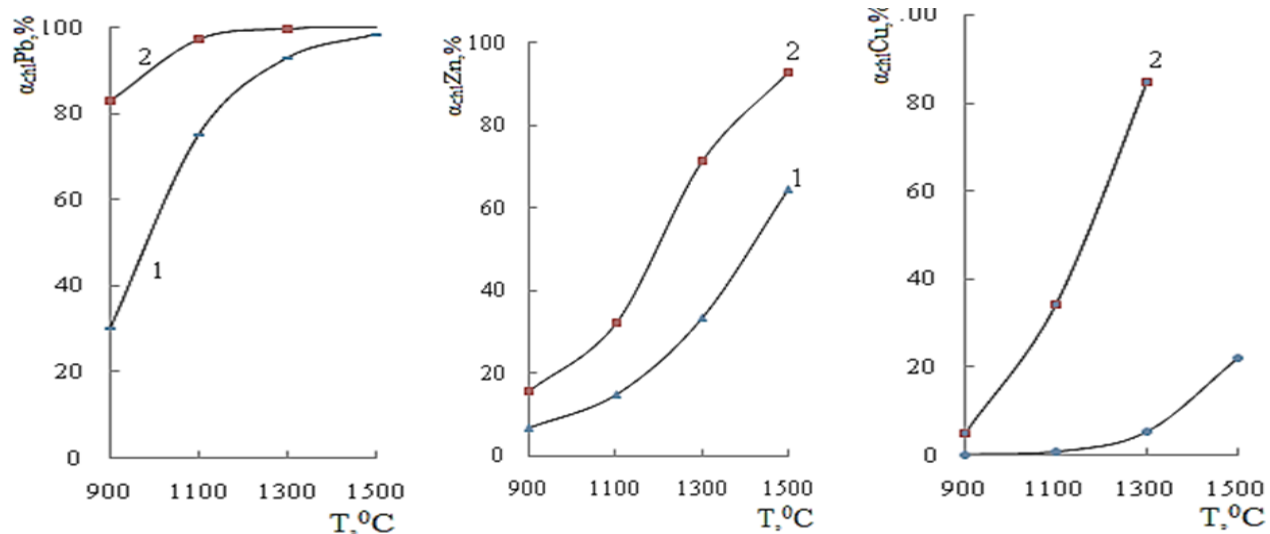

1- pressure of 1 bar; 2 - pressure of 0,1 bar

Fig. 2. Temperature effect on the chloride sublimation degree of lead, zinc and copper from the slag in the presence of $\mathrm{CaCl}_{2}$ and $\mathrm{NaCl}$ 
Using these equations according to the technique ${ }^{11}$ solid surfaces of temperature and pressure effect on $\alpha_{c h l}(\mathrm{~Pb}), \alpha_{\mathrm{chl}}(\mathrm{Zn})$ and $\alpha_{\mathrm{chl}}(\mathrm{Cu})$ and their horizontal sections were constructed (Fig. 3). As follows from Fig. 3, $\alpha_{\text {chl }}(\mathrm{Pb})$ from 95 to $100 \%$ is observed in the area abcd, $\alpha_{\text {chl }}(\mathrm{Zn})$ from 90 to $100 \%$ - in the area xyzf and $\alpha_{\text {chl }}(\mathrm{Cu})$ - in the area nmet. Values of temperature and pressure in boundary points of these technological areas are represented in Table 4.

Table 1: The planning matrix and the research results of the lead chloride sublimation from the fuming slag

\begin{tabular}{|c|c|c|c|c|c|c|}
\hline \multirow[t]{3}{*}{ No } & \multicolumn{4}{|c|}{ Variable parameter } & \multicolumn{2}{|c|}{$\begin{array}{l}\text { Lead chloride } \\
\text { sublimation degree, \% }\end{array}$} \\
\hline & \multicolumn{2}{|c|}{ Code kind } & \multicolumn{2}{|c|}{ Natural kind } & \multirow[t]{2}{*}{$\alpha_{\text {chl (initial) }}$} & \multirow[t]{2}{*}{$\alpha_{\text {chl (calcul.) }}$} \\
\hline & $\mathrm{x}_{1}$ & $\mathrm{X}_{2}$ & IgP, bar & $\mathrm{T},{ }^{\circ} \mathrm{C}$ & & \\
\hline 1 & +1 & +1 & $-0.3(0.50)$ & 1241.8 & 95.01 & 93.63 \\
\hline 2 & +1 & -1 & $-0.3(0.50)$ & 958.2 & 76.52 & 74.79 \\
\hline 3 & -1 & +1 & $-1.7(0.02)$ & 1241.8 & 99.92 & 99.82 \\
\hline 4 & -1 & -1 & $-1.7(0.02)$ & 958.2 & 96.03 & 95.58 \\
\hline 5 & +1.414 & 0 & $-0.0(0.00)$ & 1100 & 79.04 & 80.80 \\
\hline 6 & -1.414 & 0 & $-2.0(0.01)$ & 1100 & 99.91 & 99.87 \\
\hline 7 & 0 & +1.414 & $-1.0(0.1)$ & 1300 & 99.12 & 99.74 \\
\hline 8 & 0 & -1.414 & $-1.0(0.1)$ & 900 & 123.03 & 83.42 \\
\hline 9 & 0 & 0 & $-1.0(0.1)$ & 1100 & 95.03 & 95.24 \\
\hline 10 & 0 & 0 & $-1.0(0.1)$ & 1100 & 95.32 & 95.24 \\
\hline 11 & 0 & 0 & $-1.0(0.1)$ & 1100 & 94.71 & 95.24 \\
\hline 12 & 0 & 0 & $-1.0(0.1)$ & 1100 & 94.83 & 95.24 \\
\hline
\end{tabular}

Table 2: The planning matrix and the research results ofthe zinc chloride sublimation from the fuming slag

\begin{tabular}{|c|c|c|c|c|c|c|}
\hline \multirow[t]{3}{*}{ No } & \multicolumn{3}{|c|}{ Variable parameter } & \multicolumn{3}{|c|}{$\begin{array}{l}\text { Zinc chloride } \\
\text { sublimation degree,\% }\end{array}$} \\
\hline & \multicolumn{2}{|c|}{ Code kind } & \multicolumn{2}{|c|}{ Natural kind } & \multirow[t]{2}{*}{$\alpha_{\mathrm{chl} \text { (initial) }}$} & \multirow[t]{2}{*}{$\alpha_{\text {chl (calcul.) }}$} \\
\hline & $X_{1}$ & $\mathrm{X}_{2}$ & $\lg \mathrm{P}(\mathrm{bar})$ & $\mathrm{T},{ }^{\circ} \mathrm{C}$ & & \\
\hline 1 & +1 & +1 & $-0.3(0.50)$ & 1441.8 & 70.02 & 68.48 \\
\hline 2 & +1 & -1 & $-0.3(0.50)$ & 1158.2 & 22.21 & 18.72 \\
\hline 3 & -1 & +1 & $-1.7(0.02)$ & 1441.8 & 65.33 & 66.51 \\
\hline 4 & -1 & -1 & $-1.7(0.02)$ & 1158.2 & 33.33 & 36.68 \\
\hline 5 & +1.414 & 0.0 & $-0.0(0.00)$ & 1300.0 & 95.01 & 91.61 \\
\hline 6 & -1.414 & 0.0 & $-2.0(0.01)$ & 1300.0 & 92.02 & 90.75 \\
\hline 7 & 0.0 & +1.414 & $-1.0(0.1)$ & 1500.0 & 31.84 & 33.04 \\
\hline 8 & 0.0 & -1.414 & $-1.0(0.1)$ & 1100.0 & 71.01 & 71.72 \\
\hline 9 & 0.0 & 0.0 & $-1.0(0.1)$ & 1300.0 & 71.02 & 71.72 \\
\hline 10 & 0.0 & 0.0 & $-1.0(0.1)$ & 1300.0 & 72.33 & 71.72 \\
\hline 11 & 0.0 & 0.0 & $-1.0(0.1)$ & 1300.0 & 73.12 & 71.72 \\
\hline 12 & 0.0 & 0.0 & $-1.0(0.1)$ & 1300.0 & 71.63 & 71.72 \\
\hline 13 & 0.0 & 0.0 & $-1.0(0.1)$ & 1300 & 71.71 & 71.72 \\
\hline
\end{tabular}

Table 3: The planning matrix and the research results of the copper chloride sublimation from the fuming slag

\begin{tabular}{|c|c|c|c|c|c|c|}
\hline \multirow[t]{3}{*}{ No } & \multicolumn{3}{|c|}{ Variable parameter } & \multicolumn{3}{|c|}{$\begin{array}{c}\text { Copper chloride } \\
\text { sublimation degree,\% }\end{array}$} \\
\hline & \multicolumn{2}{|c|}{ Code kind } & \multicolumn{2}{|c|}{ Natural kind } & \multirow[t]{2}{*}{$\alpha_{\text {chl(initial) }}$} & \multirow[t]{2}{*}{$\alpha_{\text {chl (calcul.) }}$} \\
\hline & $X_{1}$ & $X_{2}$ & $\lg \mathrm{P}(\mathrm{bar})$ & $\mathrm{T},{ }^{\circ} \mathrm{C}$ & & \\
\hline 1 & +1 & +1 & $-0.3(0.50)$ & 1370.7 & 36.42 & 41.10 \\
\hline 2 & +1 & -1 & $-0.3(0.50)$ & 1329.3 & 12.21 & 8.93 \\
\hline 3 & -1 & +1 & $-1.7(0.02)$ & 1370.7 & 97.21 & 98.13 \\
\hline 4 & -1 & -1 & $-1.7(0.02)$ & 1329.3 & 88.02 & 80.57 \\
\hline 5 & +1.414 & 0.0 & $-0.0(0.00)$ & 1400.0 & 13.03 & 11.22 \\
\hline 6 & -1.414 & 0.0 & $-2.0(0.01)$ & 1400.0 & 98.11 & 102.0 \\
\hline 7 & 0.0 & +1.414 & $-1.0(0.1)$ & 1500.0 & 80.32 & 75.24 \\
\hline 8 & 0.0 & -1.414 & $-1.0(0.1)$ & 1300.0 & 33.13 & 40.07 \\
\hline 9 & 0.0 & 0.0 & $-1.0(0.1)$ & 1400.0 & 64.52 & 64.32 \\
\hline 10 & 0.0 & 0.0 & $-1.0(0.1)$ & 1400.0 & 63.04 & 64.32 \\
\hline 11 & 0.0 & 0.0 & $-1.0(0.1)$ & 1400.0 & 62.92 & 64.32 \\
\hline 12 & 0.0 & 0.0 & $-1.0(0.1)$ & 1400.0 & 65.23 & 64.32 \\
\hline 13 & 0.0 & 0.0 & $-1.0(0.1)$ & 1400.0 & 63.91 & 64.32 \\
\hline
\end{tabular}

As follows from the data of Table 4, to achieve the $95-100 \%$ lead chloride sublimation degree the necessary temperature is $933.7-1300^{\circ} \mathrm{C}$ and IgP should be from -0.48 to -1.75 (pressure of 0.33-0.0177 bar); for achievement of the $90.0-100 \%$ chloride sublimation degree for zinc respective parameters are $\mathrm{T}=1279.3-1500^{\circ} \mathrm{C}$ and $\mathrm{lgP}$ from -0.972 to -2 (pressure of 0.107-0,01 bar), for copper temperature of $1337.7-1500^{\circ} \mathrm{C}$ and $\mathrm{lgP}$ from -1.418 to -2 (pressure of $0.038-0.01$ bar). Judging by the table data, at pressure of 0.01 bar the high copper chloride sublimation degree is possible at high temperatures $\left(1337.7^{\circ} \mathrm{C}\right)$; for zinc it can be lowered to $1279.3^{\circ} \mathrm{C}$ and for lead - to $933.7^{\circ} \mathrm{C}$. At implementation of the sinter-chlorinating roasting of the slags the process temperature should not exceed the slag's melting temperature $\left(1200^{\circ} \mathrm{C}^{12}\right)$, that is its maximal value may be $1100-1150^{\circ} \mathrm{C}$. For achievement of high $\alpha_{\mathrm{chl}}(\mathrm{Zn})$ and $\alpha_{\text {chl }}(\mathrm{Cu})$ values at these temperatures the process pressure should be reduced.

The information about influence of the pressure reduction on $\alpha_{\text {chl }}(\mathrm{Cu})$ at the lowered temperatures $\left(1100-1150^{\circ} \mathrm{C}\right)$ is represented in Table 5.

It is evident, that at temperature of $1150^{\circ} \mathrm{C}$ and pressure of 0.001 bar $\alpha_{\text {chl }}(\mathrm{Cu})$ exceeds $85 \%$. At the same time, zinc and lead completely pass in a gaseous condition. 

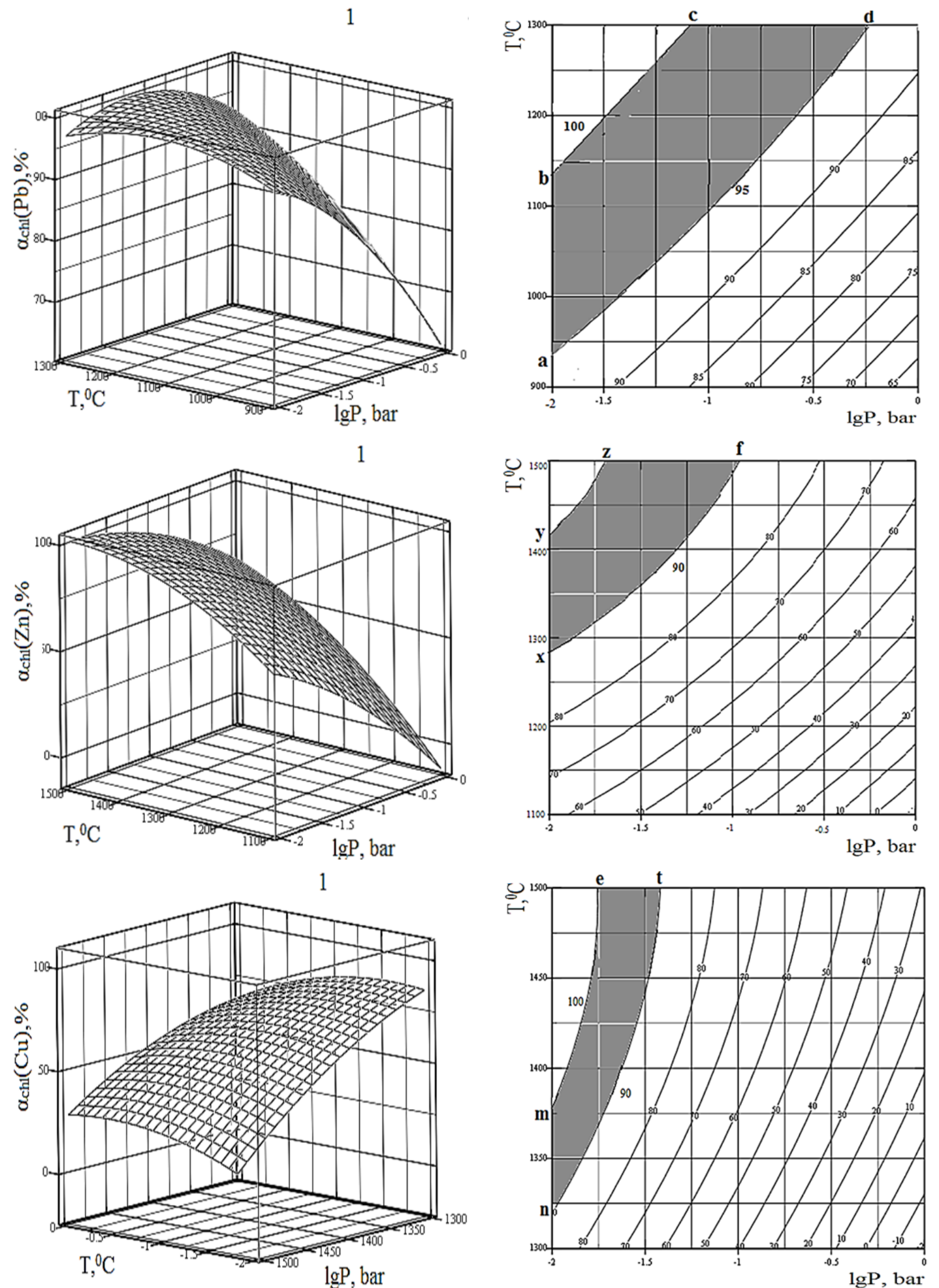

1- the solid representation; 2 - the horizontal section

Fig. 3. Temperature and pressure effect on the chloride sublimation degree of lead, zinc and copper in a system slag $-(\mathrm{CaCl} 2+\mathrm{NaCl})-\mathrm{O}_{2}$ 


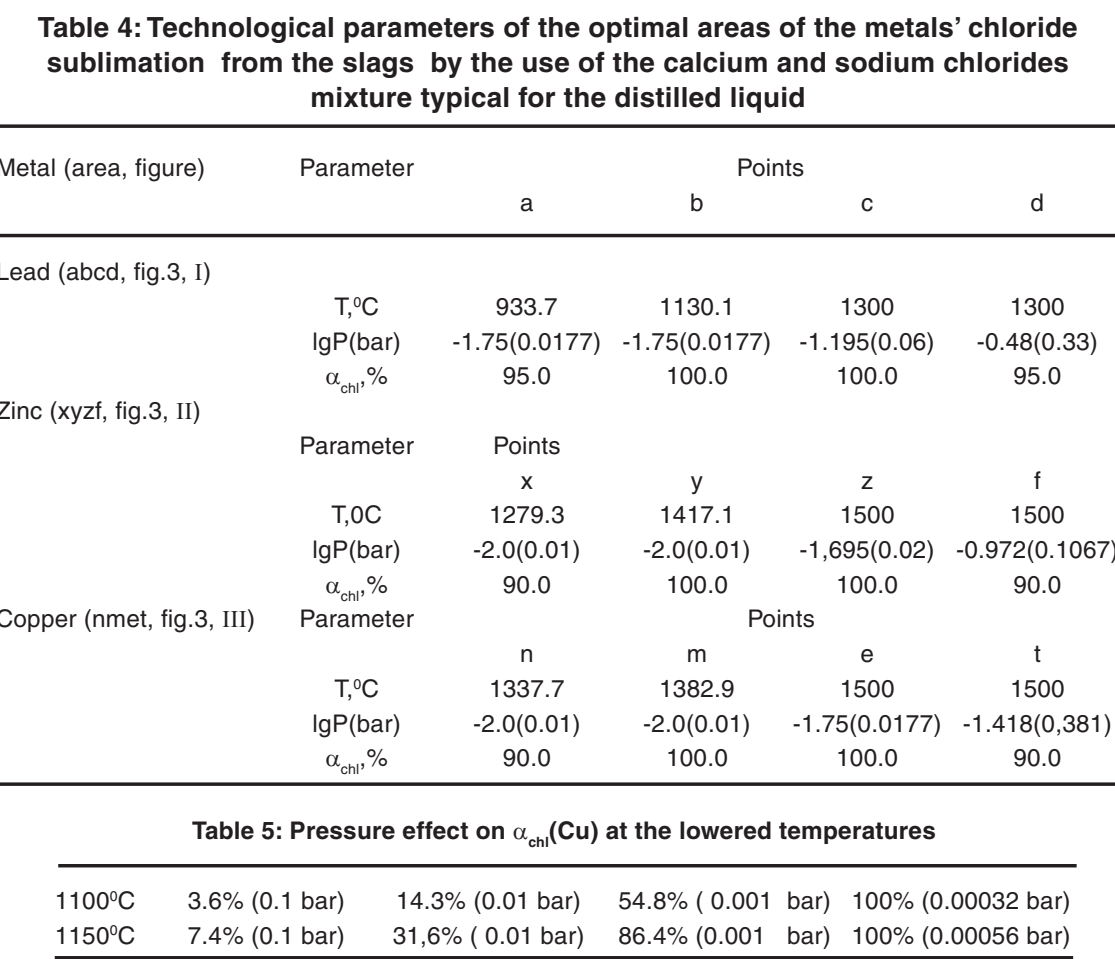

The experiments connected with determination of the possibility of application of the distilled liquid for extraction of lead, zinc and copper from the fuming slags

The experiments connected with determination of the possibility of application of the distilled liquid for extraction of lead, zinc and copper from the fuming slags were carried out on a sintering plant $^{13}$. The charge mass was $300-350$ g. Before the sintering roasting the slag and coal (5\% of the slag mass) are grinded to the fraction $<0.1 \mathrm{~mm}$ and pelletized using a solution of the distilled liquid. The granules in diameter of 1-1.2 $\mathrm{cm}$ were dried at $200^{\circ} \mathrm{C}$ during 30 minutes. The dry granules were loaded on a fire grate of an agglomeration cylinder (on which we preliminary placed a burnt limestone layer). Ignition of the granules is realized by means of a blowtorch. After the ignition (in 5-8 $\mathrm{min}$ ) the layer wise burning of the charge with the simultaneous chloride sublimation of the metals occurred. Suction of the gases (including the chloride sublimation gases) is realized with the help of a smoke sucker. Vacuum under the fire-grate was controlled by a manometre. Duringthe ignition periodit was0.006-0.0065 bar, and during thechloride sublimation period $-0.01-0.015$ bar. The process duration was 35-40 minutes. Temperature of the material in the layer was $1150-1180^{\circ} \mathrm{C}$. The metals' chloride sublimation degree was calculated under the formula:

$$
\begin{aligned}
\alpha_{x 7}(\mathrm{Me})= & \frac{\mathrm{G}_{\mathrm{Me}(\text { slag })-\mathrm{G}_{\mathrm{Me}(\text { sin })}}}{\mathrm{G}_{\mathrm{Me}(\text { slag })}} \cdot 100 \\
& \text { Where } \mathrm{G}_{\left(\mathrm{Me}(\mathrm{slag})^{H}\right.} \mathrm{G}_{(\mathrm{Me}(\sin )} \text {-mass of a metal in }
\end{aligned}
$$
a slag and in a sinder after roasting, $\mathrm{g}$.

On the basis of the results of 3 experiments it was found, that the chloride sublimation degreeof coppermade $73-88 \%$, zinc - 82-96\% and lead - 93$98 \%$.

\section{CONCLUSION}

On the ground of the results of the experiments on application of the distilled liquid - the waste of soda manufacture - for extraction of lead, zinc and copper from the dump slags by chloride sublimation it is possible to draw the following conclusions:

- $\quad$ at equilibrium conditions lead is extracted the most effectively from the slags by chloride sublimation, then zinc and copper: at pressure of 1 bar and temperature of $1500^{\circ} \mathrm{C}$ the chloride sublimation degree for lead makes 
$98.63 \%$, for zinc $-64.45 \%$ and for copper $21.91 \%$;

to achieve the $95-100 \%$ lead chloride sublimation degree the needed temperature is $933.7-1300^{\circ} \mathrm{C}$ and $\operatorname{lgP}$ should be from -0.48 to -1.75 (pressure of 0.33-0.0177 bar); for achievement of the $90.0-100 \%$ chloride sublimation degree for zinc respective parameters are $\mathrm{T}=1279.3-1500^{\circ} \mathrm{C}$ and IgP from -0.972 to -2 (pressure of 0.107 0,01 bar), for copper - temperature of 1337.7$1500^{\circ} \mathrm{C}$ and $\operatorname{lgP}$ from -1.418 to -2 (pressure of 0.038-0.01 bar);

- $\quad$ it was experimentally proved, that at the sinter-chlorinating roasting at temperature of $1150-1180^{\circ} \mathrm{C}$ and pressure of $0.006-0.001$ bar the chloride sublimation degree for lead makes $93-98 \%$, for zinc - 82-96\%, for copper $-73-88 \%$.

\section{ACKNOWLEDGMENT}

The work was supported by projects of the Ministry of Education and Sciences of the Republic of Kazakhstan.

\section{Conflicts of Interest}

The authors declare no conflict of interest.

\section{REFERENCES}

1. Lotosh, V.E. Processing of wastes of natural application. Yekaterinburg:University UST,(Russian)., 2002, 463.

2. Bakhonina, E.I.; Bikbulatov, I.H.; Bakiyev, A.Yu.; Daminev, R.R.; Nasyrov, R.R.; Oparina, F.R. A waterless calcium peroxide production way, RU2341449, 23.05.2007.

3. Isayev, A.B.; Aliyev, Z.M.; Abdullaeva, N.A. A phosphorus-containing fertilizers production way, RU2398753, Publ. 10.09.2010.

4. Mukhametov, A.A.; Voronin, A.V.; Sadykov, N.B.; Mustafin, A.G.; Mukhametov, A.A. An ammonium chloride production way, RU2495824, 20.10.2013.

5. Mikhailova, E.A; Loboiko, A.Ya.; Molchanov V.I.; Panasenko, V.A. Theses of reports of the international conference "Cooperation for solving of the waste problem"(Russian), 2004, 177-178.

6. Tkach G.A., Shaporev V.P., Titov. V.M. Soda manufacture according toa low-waste technology. Kharkov,(Russian)., 1998.

7. Bykovsky, N.A.; Kurbangaleyeva, L.R.; Daminev R.R. Basic research, (Russian)., 2012, 6(1), 209-213.
8. Ghosh, P.K.; Mody, H.M.; Somani, R.S.; Maiti P.R.; Gandhi, M.R.; Bajaj, H.C.; Chunawala, J.R.; Upadhyay, S.C. Method of recycling of by-products for the production of soda ash and ammonium sulphate, US patent application 20150093309A1, 02.04.2015.

9. Roine, A. Outokumpu HSC Chemistry for Windows. Chemical Reaction and Eguilibrium software with Extensive Thermochemical Database. Pori: Outokumpu Research OY, 2002.

10. Akhnazarova, S.L.; Kafarov, V.V. Methods of experiment optimisation in the chemical industry. Moscow: Higher school, (Russian)., 1978, 319.

11. Ochkov, V.F. Mathcad-14 for students, engineers and designers.St.Petersburg: BHVPeterburg,(Russian)., 2007.

12. Daribaev, Zh.Ye.; Shevko, V.M.Sinterchlorinating roasting of concentration tailings and overburden rocks. Kentau, (Russian)., 2004, 211.

13. Shevko, V.M.; Karatayeva, G.Ye. Metallurgy of zinc and cadmium. Shymkent, (Russian)., 2015, 350. 